Article

\title{
Bioactive Constituents of F. esculentum Bee Pollen and Quantitative Analysis of Samples Collected from Seven Areas by HPLC
}

\author{
Feng Li ${ }^{1, \dagger}$, Sen Guo ${ }^{1,2,+}$, Shanshan Zhang ${ }^{1}$, Sainan Peng ${ }^{1}$, Wei Cao ${ }^{2}$, Chi-Tang Ho ${ }^{3, *}$ and \\ Naisheng Bai ${ }^{2, *}$ \\ 1 College of Chemical Engineering, Department of Pharmaceutical Engineering, Northwest University, Taibai \\ North Road 229, Xi'an 710069, China \\ 2 College of Food Science and Technology, Northwest University, Taibai North Road 229, Xi'an 710069, China \\ 3 Department of Food Science, Rutgers University, 65 Dudley Road, New Brunswick, NJ 08901, USA \\ * Correspondence: ctho@sebs.rutgers.edu (C.-T.H.); nsbai@nwu.edu.cn (N.B.); \\ Tel.: +1-848-932-5553 (C.-T.H.); +86-29-88305682 (N.B.) \\ + Indicates co-first author.
}

Received: 16 June 2019; Accepted: 22 July 2019; Published: 25 July 2019

\begin{abstract}
Bee pollen contains all the essential amino acids needed by humans. China is the largest producer of bee pollen in the world. In the present study, we identified 11 fatty acids in F. esculentum bee pollen oil by GC-MS analysis, and 16 compounds were isolated from F. esculentum bee pollen by column chromatography and identified. A high-performance liquid chromatography-diode array detector (HPLC-DAD) method was established for the quality control of F. esculentum bee pollen. A validated HPLC-DAD method was successfully applied to the simultaneous characterization and quantification of nine main constituents in seven samples collected from seven different areas in China. The results showed that all standard calibration curves exhibited good linearity $\left(R^{2}>0.999\right)$ in HPLC-DAD analysis with excellent precision, repeatability and stability. The total amount in the samples from the seven regions ranged from 23.50 to $46.05 \mathrm{mg} / \mathrm{g}$. In addition, seven compounds were studied for their bioactivity using enzymic methods, whereby kaempferol (3) showed high $\alpha$-glucosidase inhibitory activity ( $\mathrm{IC}_{50}: 80.35 \mu \mathrm{g} / \mathrm{mL}$ ), ergosterol peroxide (8) showed high tyrosinase inhibitory activity $\left(\mathrm{IC}_{50}: 202.37 \mu \mathrm{g} / \mathrm{mL}\right)$, and luteolin (1) had strong acetylcholinesterase inhibitory activity $\left(\mathrm{IC}_{50}: 476.25 \mu \mathrm{g} / \mathrm{mL}\right.$ ). All results indicated that $F$. esculentum bee pollen could be a nutritious health food.
\end{abstract}

Keywords: bee pollen; enzyme inhibitory activity; HPLC-DAD; GC-MS; quality analysis

\section{Introduction}

Bee pollen (BP), one of the hive products in addition to honey, royal jelly and propolis, is gaining attention due to the presence of bioactive compounds associated with beneficial health properties $[1,2]$. The BP composition varies due to the plant species and is also influenced by age, nutritional condition of the plant, differences in gathering area and time as well as environmental conditions during pollen development [3-6]. Monofloral pollen pellets maintain organoleptic and biochemical properties similar to those of the original plant, whereas the multifloral pollen has variable properties of more than two original plants [7]. Generic bee pollen composition data were considered sufficient for most purposes, but now the usefulness of bee pollen-specific composition data is increasingly being acknowledged [8,9]. Recent research has also shown that bee pollen possesses therapeutic benefits for improving the cardiovascular system, stimulating body immunity [10], promoting antitumor effects, 
delaying aging [11], scavenging free radicals, regulating intestinal function [12], and treating prostate disease [13-17].

$\alpha$-Glucosidase (AG) is an important enzyme to maintain the normal metabolism of the human body. It hydrolyzes maltose and sucrose by catalyzing the hydrolysis of 1,4-glycosidic bonds in sugar, which is widely distributed in human body and plays a crucial role in human metabolism [18]. Acetylcholinesterase (AChE) is a major functional enzyme that hydrolyzes acetylcholine (ACh) in the central nervous system. Anatomical studies have found that AChE protein expression in the brain of Alzheimer's disease (AD) patients is elevated $[19,20]$. In recent years, there have been more and more studies on acetylcholinesterase inhibitors [21]. The drugs approved by the US Food and Drug Administration (FDA) for the treatment of AD are mainly AChE inhibitors, including donepezil, rivastigmine and tacrine [22], but they also have significant side effects and toxicity, and low bioavailability. Therefore, the search for new natural products as a safe and non-toxic AChE inhibitors is urgently needed.

Melanin is one of the natural pigments responsible for skin pigmentation and hair color in mammals [23]. The excessive production of melanin results in hyperpigmentation dysfunctions, along with aging [24]. Tyrosinase, a copper-containing enzyme involved in melanin biosynthesis [25], is the only enzyme found to regulate the generation of melanin in humans. The investigation of tyrosinase inhibitors may lead to the development of new skin-whitening substances, medicinal agents and anti-browning constituents [26]. Various potential tyrosinase inhibitors from natural products have been found, and they have attracted attention because of their safety and abundance [27]. This promote us to investigate the tyrosinase inhibitory activity isolated from F. esculentum bee pollen.

In the light of this, we studied the composition of F. esculentum pollens and quantitatively analyzed F. esculentum pollens collected from different areas in China. Nine compounds, including flavonoids, phenolic acids and polyphenols were analyzed by a validated HPLC-DAD method. We also carried out enzyme activity experiments to verify their $\alpha$-glucosidase inhibitory activity, tyrosinase inhibitory activity and acetylcholinesterase inhibitory activity. The obtained quantitative data will be useful for quality control of F. esculentum pollens for their comprehensive use as a functional food.

\section{Materials and Methods}

\subsection{Chemicals, Regents and Materials}

Seven batches of BPs, consisting of Fagopyrum esculentum Moench from different production areas in China, were collected in 2016. These samples were identified by the corresponding author (NB). Their voucher specimens were deposited in a refrigerator at $4{ }^{\circ} \mathrm{C}$ at the Department of Pharmaceutical Engineering, Northwest University, China. BPSX was from Shannxi, BPAH was from Anhui, BPNM was from Neimeng, BPHN was from Heinan, BPGS was from Gansu, BPHB1 was from Hebei and BPHB2 was from Hubei.

Silica gel (100-200 mesh), MCI GEL CHP-20P (Mitsubishi Kasei Co., Tokyo, Japan) and Sephadex LH-20 (Sigma Chemical Co., St. Louis, MO, USA) were used for column chromatographic separations. Thin layer chromatography (TLC) was performed on Sigma-Aldrich silica gel TLC plates $(250 \mu \mathrm{m}$ thickness, 2-25 $\mu \mathrm{m}$ particle size). Acetonitrile was of HPLC grade from Merck (Darmstadt, Germany). Water was purified with a sub boil high purity water still (SYZ 550, Tianjin, China). Other reagents such as ethyl alcohol, $\mathrm{CH}_{2} \mathrm{Cl}_{2}$ and methanol used in this experiment were of analytical grade and purchased from Hengxing Chemical Reagent Co., Ltd. (Tianjin, China). The 4-nitrophenyl $\beta$-D-glucopyranoside (PNPG), acarbose, L-arginine, kojic acid, acetylthiocholine iodide (ACTI), 5,5'-dithiobis(2-nitrobenzoic acid) (DTNB), and huperzine A used in the activity experiments were all from Shanghai Aladdin Biochemical Technology Co., Ltd. (Shanghai, China). We have isolated the standard substances 1-16 and their structures were fully characterized by chemical and spectroscopic methods (NMR and MS data are provided as Supplementary Materials). They are luteolin (1), resveratrol (2), kaempferol (3), $\beta$-daucosterol (4), caffeic acid (5), chlorogenic acid (6), rutin (7), 
ergosterol peroxide (8), octacosanol (9), 2- $\beta$-D-glucopyranosyloxy-1-hydroxytrideca-3,5,7,9,11-pentayne (10), $\alpha$-D-Alt- $p$-OMe (N2-6) $\alpha$-D-Gle- $p$-OMe (11), O- $\alpha$-D-glucopyranosyl-(1 $\rightarrow 4)$ - $\alpha$-D-glucopyranosyl$(1 \rightarrow 4)$ - $\alpha$-D-glucopyranosyl-( $1 \rightarrow 2)$ - $\beta$-D-fructofuranoside (12), catechin (13), quercitrin (14), oleanolic acid (15) and tyrosol (16). The purity of each compound was $>98 \%$, determined by HPLC analysis. The chemical structures of these reference compounds are shown in Figure 1.



Figure 1. Chemical structures of the 16 identified compounds in F. esculentum pollens.

\subsection{HPLC Conditions}

HPLC analysis was performed on a 1260 LC Series system (Agilent, Palo Alto, CA, USA) using a Luna C-18 column (5 micron, 4.6 mm I.D. $\times 250$, Phenomenex, Inc. Torrance, CA, USA) with a flow rate of $1.0 \mathrm{~mL} / \mathrm{min}$, and the column temperature was maintained at $20{ }^{\circ} \mathrm{C}$. Injection volume were $10 \mu \mathrm{L}$ for the standard solutions and $15 \mu \mathrm{L}$ for sample solutions. The mobile phase was composed of $\mathrm{C}$ (methanol) and D (water) with a gradient elution: $0 \mathrm{~min}, 95 \% \mathrm{D} ; 0-6 \mathrm{~min}, 95-92 \% \mathrm{D} ; 6-11 \mathrm{~min}, 92-90 \%$ D; 11-17 $\min , 90-86 \%$ D; 17-25 min, 86-75\% D; 25-30 min, 75-70\% D; 30-40 min, 70-45\% D; 40-47 $\mathrm{min}$, $45-30 \% \mathrm{D} ; 47-55 \mathrm{~min}, 30-5 \% \mathrm{D} ; 55-70 \mathrm{~min}, 5-95 \% \mathrm{D}$. At the end of the run, 95\% of acetonitrile was used to flush the column for $5 \mathrm{~min}$ and an additional $5 \mathrm{~min}$ of post run time were set to allow for equilibration of the column with the starting eluant. UV detector was set at $210 \mathrm{~nm}$ wavelength for the compounds during the experiment.

\subsection{Saponification and Methylation for Fatty Acids (FAs)}

The F. esculentum pollen oils were obtained by a pressing method under low temperature, and processed by saponification and methylation reactions for further GC-MS analysis. Briefly, $0.5 \mathrm{~g}$ of F. esculentum pollens oil prepared above was dissolved in $4 \mathrm{~mL}$ methanol solution containing $0.5 \mathrm{~mol} / \mathrm{L}$ of potassium hydroxide, stirred for $2 \mathrm{~min}$, and kept in a $60^{\circ} \mathrm{C}$ water bath for $1 \mathrm{~h}$ in a capped test tube to induce saponification for derivatization. Then, $3 \mathrm{~mL}$ of methanol solution containing $10 \%$ concentrated sulphuric acid was added, the sample was again placed in a $60{ }^{\circ} \mathrm{C}$ water bath for $1 \mathrm{~h}$. After reactions, 
the sample was cooled to room temperature. Subsequently, $3 \mathrm{~mL}$ of deionized water and $6 \mathrm{~mL}$ of n-hexane were added for extraction. After centrifugation (13,000 rpm, $10 \mathrm{~min})$, the supernatant was obtained and dried using a nitrogen flow. The obtained solution was stored in a refrigerator at $4{ }^{\circ} \mathrm{C}$ and filtered through a $0.45 \mu \mathrm{m}$ nylon-membrane filter prior to injection into the GC-MS analysis.

\subsection{GC-MS Analysis}

The FA profiles in the pollen oils were analyzed by GC-MS as their corresponding methyl ester. The oil sample was analyzed three times under the same conditions. The GC-MS (Agilent 6590N Network System, M 5973N) instrument was coupled with a Rtx-5MS column $(30 \mathrm{~m} \times 0.25 \mathrm{~mm} \times 0.25 \mu \mathrm{m}(5 \%$ phenylmethylsiloxane) $)$. Helium (purity, 99.99\%) was used as the carrier gas at a flow rate of $3.0 \mathrm{~mL} / \mathrm{min}$. The injection volume is $1 \mu \mathrm{L}$ by split (1:30). Injector, source and oven temperatures were $250^{\circ} \mathrm{C}, 200{ }^{\circ} \mathrm{C}$ and $120^{\circ} \mathrm{C}$, respectively. The initial oven temperature $120^{\circ} \mathrm{C}$ held for $2.5 \mathrm{~min}$ and then ramped at $10^{\circ} \mathrm{C} / \mathrm{min}$ to $180^{\circ} \mathrm{C}$, ramped at $1.5^{\circ} \mathrm{C} / \mathrm{min}$ to $210^{\circ} \mathrm{C}$, ramped at $5{ }^{\circ} \mathrm{C} / \mathrm{min}$ to $250^{\circ} \mathrm{C}$ and last for $3 \mathrm{~min}$.

\subsection{Extraction and Isolation}

The BPs (15 kg from Shanxi) was percolated with 90\% EtOH at room temperature for three times, then the EtOH extracts were combined. The extract $(6.32 \mathrm{~kg})$ was suspended in $\mathrm{H}_{2} \mathrm{O}(6.5 \mathrm{~L})$ and then extracted exhaustively with $\mathrm{PE}, \mathrm{EtOAc}$ and $n$-BuOH (6.5 L each) 3 times. The $n$-BuOH solution containing $195.3 \mathrm{~g}$ of solid was chromatographed on a silica gel column $(15 \mathrm{~L}, 8.0 \mathrm{~cm} \times 120 \mathrm{~cm})$ with $\mathrm{CH}_{2} \mathrm{Cl}_{2}-\mathrm{MeOH}$ (100:1-0:1) gradient to give seven crude fractions (Fr.1-7).

Fr.2, Fr.3 and Fr.4 were repeatedly subjected to silica gel column with $\mathrm{CH}_{2} \mathrm{Cl}_{2}$-EtOAc, then they were repeatedly subjected to MCI GEL CHP-20P column with water-MeOH system (start from $\mathrm{H}_{2} \mathrm{O}$ and increased $\mathrm{MeOH}$ ratio to $10-100 \% \mathrm{MeOH}$ ) to give compound 7 (21 mg from fraction 2-3-3, $\left.t_{\mathrm{R}}=48.34 \mathrm{~min}\right), 16$ (21 $\mathrm{mg}$ from fraction $\left.3-3, t_{\mathrm{R}}=51.04 \mathrm{~min}\right), 3\left(12 \mathrm{mg}\right.$ from fraction $\left.4-3, t_{\mathrm{R}}=49.10 \mathrm{~min}\right)$, 5 (10 mg from fraction $4-2-2, t_{\mathrm{R}}=30.47 \mathrm{~min}$ ) and 6 (9 mg from fraction $\left.4-3, t_{\mathrm{R}}=29.53 \mathrm{~min}\right)$. Fr. 5 and Fr. 6 were repeatedly subjected to MCI GEL CHP-20P column and/or Sephadex LH-20 column with water- $\mathrm{MeOH}$ system (start from $\mathrm{H}_{2} \mathrm{O}$ and increased $\mathrm{MeOH}$ ratio to $10-100 \% \mathrm{MeOH}$ ) to give compound $13\left(25 \mathrm{mg}\right.$ from fraction $\left.5-4, t_{\mathrm{R}}=44.85 \mathrm{~min}\right), 14\left(26 \mathrm{mg}\right.$ from fraction $\left.5-3, t_{\mathrm{R}}=54.91 \mathrm{~min}\right), \mathbf{1}(15 \mathrm{mg}$ from fraction $\left.6-2-2, t_{\mathrm{R}}=47.89 \mathrm{~min}\right), 2$ (16 $\mathrm{mg}$ from fraction $6-4, t_{\mathrm{R}}=32.26 \mathrm{~min}$ ) and 9 (38 $\mathrm{mg}$ from fraction $6-2-3, t_{\mathrm{R}}=62.25 \mathrm{~min}$ ). The separation process of other compounds is also as described above. Compound 4 (18 $\mathrm{mg}$ from fraction $\left.2-3-3, t_{\mathrm{R}}=57.82 \mathrm{~min}\right), 8\left(35 \mathrm{mg}\right.$ from fraction $\left.5-4, t_{\mathrm{R}}=44.01 \mathrm{~min}\right)$, 9 (38 mg from fraction 6-2-3, $\left.t_{\mathrm{R}}=62.04 \mathrm{~min}\right), 10$ (28 $\mathrm{mg}$ from fraction $\left.3-2, t_{\mathrm{R}}=31.16 \mathrm{~min}\right), 11(14 \mathrm{mg}$ from fraction $\left.3-3, t_{\mathrm{R}}=36.17 \mathrm{~min}\right), 12\left(27 \mathrm{mg}\right.$ from fraction $\left.5-2, t_{\mathrm{R}}=53.58 \mathrm{~min}\right)$ and $15(18 \mathrm{mg}$ from fraction $\left.4-2-2, t_{R}=60.54 \mathrm{~min}\right)$. Their structures are shown in Figure 1.

\subsection{Quantitative Analysis}

\subsubsection{Preparation of Sample Solutions}

Each BP material was ground to powder and sifted through an 80 mesh sieve. Subsequently, $5 \mathrm{~g}$ of pulverized samples were accurately weighed, and extracted with ultrasonication using $40 \mathrm{~mL}$ of $90 \%$ methanol (volume fraction) for $1.5 \mathrm{~h}$. After centrifugation (13,000 rpm, $10 \mathrm{~min}$ ), the supernatant was concentrated and transferred into a $5 \mathrm{~mL}$ volumetric flask. The obtained solution was stored in a refrigerator at $4{ }^{\circ} \mathrm{C}$ and filtered through a $0.45 \mu \mathrm{m}$ filter prior to HPLC analysis.

\subsubsection{Preparation of Standard Solutions}

Nine reference standards were accurately weighed $(10,000 \mathrm{mg})$ respectively, then dissolved in methanol and a small amount of dimethyl sulfoxide to final concentrations of $1.0 \mathrm{mg} / \mathrm{mL}$. Every standard stock solution was diluted with methanol to five appropriate concentrations $(500 \mu \mathrm{g} / \mathrm{mL}$, 
$250 \mu \mathrm{g} / \mathrm{mL}, 100 \mathrm{mg} / \mathrm{mL}, 50 \mu \mathrm{g} / \mathrm{mL}$ and $10 \mu \mathrm{g} / \mathrm{mL})$. All the standard solutions were stored at $4{ }^{\circ} \mathrm{C}$ in darkness for HPLC analysis.

\subsubsection{Identification and Quantification}

Identification of these analytes were carried out by comparing the HPLC retention time and UV spectra of target peaks with those of the standards. Quantification was performed on the basis of linear calibration plots of the peak areas versus the concentration. The results are presented in Figure 2. Quantification was performed on the basis of linear calibration curves.

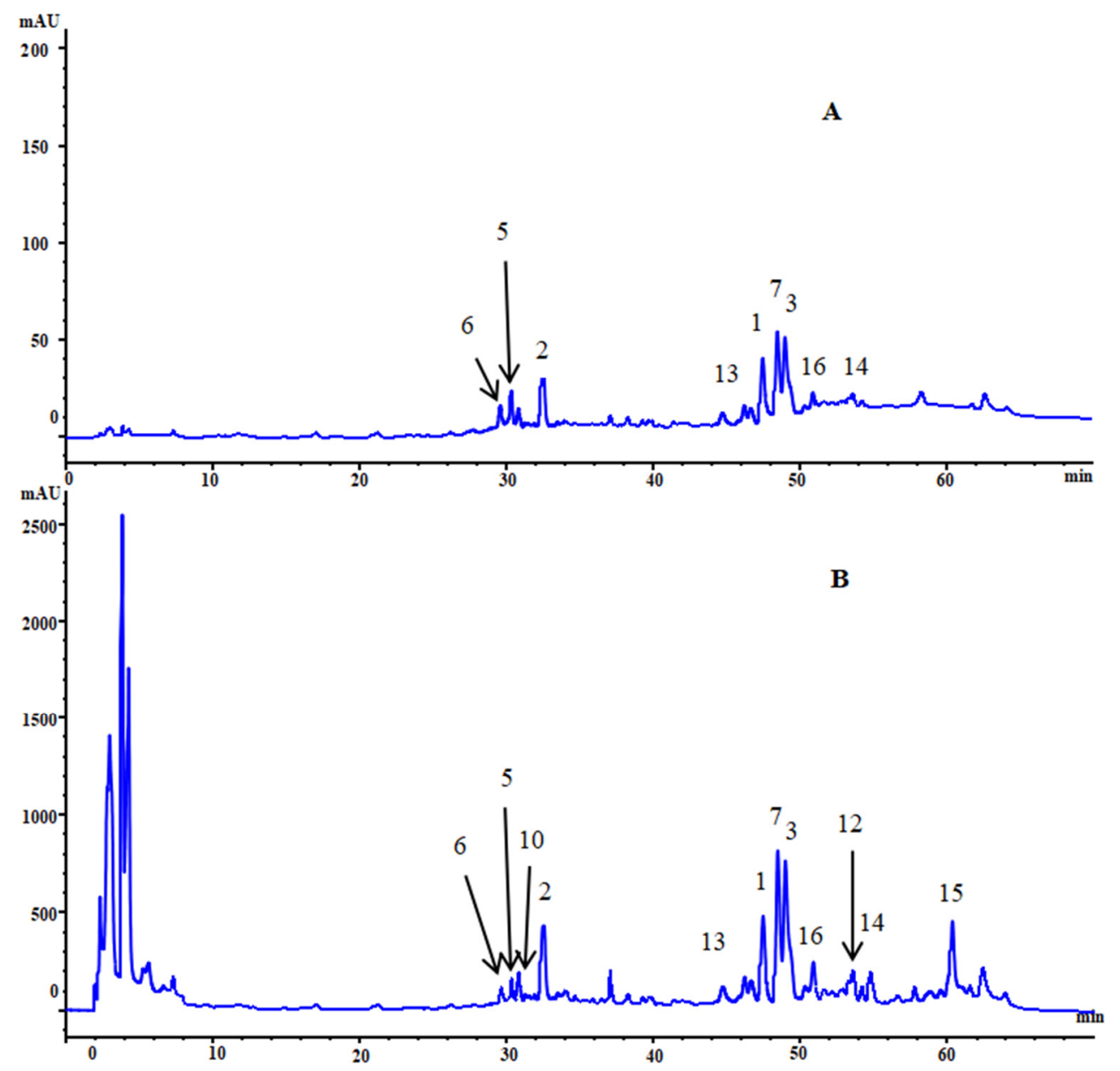

Figure 2. HPLC chromatograms of solution of standards (A) and samples (B) at 210 nm. Peaks: luteolin (1), resveratrol (2), kaempferol (3), caffeic acid (5), chlorogenic acid (6), rutin (7), 2- $\beta$-D-glucopyranosyloxy-1-hydroxytrideca-3,5,7,9,11-pentayne (10), O- $\alpha$-Dglucopyranosyl-( $1 \rightarrow 4)$ - $\alpha$-D-glucopyranosyl-( $1 \rightarrow 4)-\alpha$-D-glucopyranosyl-( $1 \rightarrow 2)$ - $\beta$-D-fructofuranoside (12), catechin (13), quercitrin (14), oleanolic acid (15) and tyrosol (16).

\subsection{Bioactivity Assay}

\subsection{1. $\alpha$-Glucosidase Inhibitory Activity Experiment}

In a 96-well plate, group A was added $20 \mu \mathrm{L}$ of $0.1 \mathrm{~mol} / \mathrm{L}$ PBS (phosphate buffered saline (pH 7.4)), $20 \mu \mathrm{L}$ of the sample (standard solution dissolved in DMSO to the concentration of $1.0 \mathrm{mg} / \mathrm{mL}$ ) and $20 \mu \mathrm{L}$ of $\alpha$-glucosidase as a sample group $(n=3)$; Group B was added $40 \mu \mathrm{L}$ of $0.1 \mathrm{~mol} / \mathrm{L}$ PBS and 20 $\mu \mathrm{L}$ of the sample as the control group $(n=3)$; Group $\mathrm{C}$ was added $40 \mu \mathrm{L} 0.1 \mathrm{~mol} / \mathrm{L} \mathrm{PBS}$ and $20 \mu \mathrm{L}$ $\alpha$-glucosidase as blank group $(n=3)$; after incubation for $15 \mathrm{~min}$ at $37^{\circ} \mathrm{C}$, then $2.5 \mathrm{mmol} / \mathrm{L} \mathrm{PNPG}$ glycoside was added to each well and incubated at $37^{\circ} \mathrm{C}$. The reaction was stopped by adding $80 \mu \mathrm{L}$ of 
a $0.2 \mathrm{~mol} / \mathrm{L} \mathrm{Na}_{2} \mathrm{CO}_{3}$ solution to each well after $15 \mathrm{~min}$. The absorbance at a wavelength of $405 \mathrm{~nm}$ was measured with a microplate reader. Acarbose was used as a positive control. The specific grouping is shown in Table 1.

Table 1. Specific grouping and reaction system for $\alpha$-glucosidase inhibitory activity.

\begin{tabular}{ccc}
\hline Group & Reaction System & Absorbance \\
\hline A & $20 \mu \mathrm{L}$ PBS, $20 \mu \mathrm{L}$ sample, $20 \mu \mathrm{L} \alpha$-glucosidase & $\mathrm{OD}_{\mathrm{A}}$ \\
$\mathrm{B}$ & $40 \mu \mathrm{L}$ PBS, $20 \mu \mathrm{L}$ sample & $\mathrm{OD}_{\mathrm{B}}$ \\
$\mathrm{C}$ & $40 \mu \mathrm{L} \mathrm{PBS}, 20 \mu \mathrm{L} \alpha$-glucosidase & $\mathrm{OD}_{\mathrm{C}}$ \\
\hline
\end{tabular}

\subsubsection{Tyrosinase Inhibitory Activity Experiment}

In a 96-well plate, group A was added $80 \mu \mathrm{L}$ of $0.1 \mathrm{~mol} / \mathrm{L}$ PBS, $50 \mu \mathrm{L}$ of solvent (solvent used to dissolve the sample: DMSO) and $50 \mu \mathrm{L}$ of tyrosinase as a blank group $(n=2)$; group B was added $130 \mu \mathrm{L}$ of $0.1 \mathrm{~mol} / \mathrm{L}$ PBS and $50 \mu \mathrm{L}$ of solvent as blank background group $(n=2)$; group C was added with $80 \mu \mathrm{L}$ of $0.1 \mathrm{~mol} / \mathrm{L}$ PBS, $50 \mu \mathrm{L}$ of the sample (standard solution dissolved in DMSO to the concentration of $1.0 \mathrm{mg} / \mathrm{mL}$ ) and $50 \mu \mathrm{L}$ of tyrosinase as the experimental group $(n=2)$; group D were added $130 \mu \mathrm{L}$ of $0.1 \mathrm{~mol} / \mathrm{L}$ PBS and $50 \mu \mathrm{L}$ of the sample as experimental background group $(n=2)$; finally, $20 \mu \mathrm{L}$ of substrate (L-tyrosine) was added to each well to trigger the reaction, and the 96-well plate was further incubated at $37^{\circ} \mathrm{C}$. After $30 \mathrm{~min}$, the absorbance at a wavelength of $405 \mathrm{~nm}$ was measured by a microplate reader. Kojic acid was used as a positive control. The specific grouping is shown in Table 2.

Table 2. Specific grouping and reaction system for tyrosinase inhibitory activity.

\begin{tabular}{ccc}
\hline Group & Reaction System & Absorbance \\
\hline A & $80 \mu \mathrm{L}$ PBS, $50 \mu \mathrm{L}$ solvent, $50 \mu \mathrm{L}$ tyrosinase, $20 \mu \mathrm{L}$ substrate & OD $_{\mathrm{A}}$ \\
B & $130 \mu \mathrm{L} \mathrm{PBS}, 50 \mu \mathrm{L}$ solvent, $20 \mu \mathrm{L}$ substrate & OD $_{\mathrm{B}}$ \\
$\mathrm{C}$ & $80 \mu \mathrm{L} \mathrm{PBS}, 50 \mu \mathrm{L}$ tyrosinase, $50 \mu \mathrm{L}$ sample, $20 \mu \mathrm{L}$ substrate & OD $_{\mathrm{C}}$ \\
D & $130 \mu \mathrm{L}$ PBS, $50 \mu \mathrm{L}$ sample, $20 \mu \mathrm{L}$ substrate & OD $_{\mathrm{D}}$ \\
\hline
\end{tabular}

\subsubsection{Acetylcholinesterase Inhibitory Activity Experiment}

In a 96-well plate, group A was added $140 \mu \mathrm{L}$ of $0.1 \mathrm{~mol} / \mathrm{L}$ PBS, $20 \mu \mathrm{L}$ of the sample (standard solution dissolved in DMSO to the concentration of $1.0 \mathrm{mg} / \mathrm{mL}$ ) and $20 \mu \mathrm{L}$ of acetylcholinesterase as a sample group ( $n=3$ ); Group B was added with $160 \mu \mathrm{L}$ of $0.1 \mathrm{~mol} / \mathrm{L} \mathrm{PBS}$ and $20 \mu \mathrm{L}$ of the sample as a control group $(n=3)$; Group $C$ was added with $160 \mu \mathrm{L} 0.1 \mathrm{~mol} / \mathrm{L}$ PBS and $20 \mu \mathrm{L}$ acetylcholinesterase as a blank group $(n=3)$, the all were incubated at $4{ }^{\circ} \mathrm{C}$ for $20 \mathrm{~min}$, then $10 \mu \mathrm{L}$ of $15 \mathrm{mM}$ ACTI and $10 \mu \mathrm{L}$ of $2 \mathrm{mM}$ DTNB were added per well, continue incubated at $37^{\circ} \mathrm{C}$ for $20 \mathrm{~min}$, the absorbance at a wavelength of $412 \mathrm{~nm}$ was measured with a microplate reader. Huperzine A was used as a positive control. The specific grouping is shown in Table 3.

Table 3. Specific grouping and reaction system for acetylcholinesterase inhibitory activity.

\begin{tabular}{ccc}
\hline Group & Reaction System & Absorbance \\
\hline A & $140 \mu \mathrm{L}$ PBS, $20 \mu \mathrm{L}$ sample, $20 \mu \mathrm{L}$ acetylcholinesterase & OD $_{\mathrm{A}}$ \\
$\mathrm{B}$ & $160 \mu \mathrm{L}$ PBS, $20 \mu \mathrm{L}$ sample & $\mathrm{OD}_{\mathrm{B}}$ \\
$\mathrm{C}$ & $160 \mu \mathrm{L}$ PBS, $20 \mu \mathrm{L}$ acetylcholinesterase & $\mathrm{OD}_{\mathrm{C}}$ \\
\hline
\end{tabular}




\section{Results and Discussion Sections in Wrong Order-Experimental is Last-Renumber Anything Affected}

\subsection{GC-MS Analysis}

The methylated F. esculentum pollen oil was subjected to GC-MS analysis in triplicate. The unambiguous identification of the separated components was carried out by comparing their recorded mass spectra with a database (the NIST08 libraries). The components in F. esculentum pollen oil were listed according to their elution order on the non-polar Rtx-5MS column as shown in Table 2. As shown in Figure 3, the GC-MS analysis of F. esculentum pollens oil sample led to identification of 11 constituents, which correspond to $85.20 \%$ of the total contents. In the present work, $(9 Z, 12 Z, 15 Z)$-octadecatrienoic acid $\alpha$-linolenic acid, ALA) $\left(\mathrm{C} 18: 3^{\Delta 9,12,15}\right)$ was found to be dominant at the high level of $36.25 \%$, which is higher than previously reported in the literature (35.58\%) [28], followed by hexadecanoic acid (C16:0, 7.67\%) and (9Z,12Z)-octadecadienoic acid (9,12-linoleic acid, LA) (C18:2 ${ }^{\Delta 9,12}$, $3.8 \%$ ) (see Table 4). ALA and LA are the predominant $\omega-3$ and $\omega-6$ FAs for humans. Dietary intake of $\omega-3$ FAs is an effective prophylactic means associated with blood lipid, inflammatory, autoimmune and cardiovascular diseases [29-32]. Furthermore, other FAs including cis-13-eicosenoic acid (C20:1 $\left.{ }^{\Delta 13}\right)$, heptadecanoic acid (C17:0), eicosanoic acid (C20:0), octadecanoic acid (C18:0), tetradecanoic acid (C14:0) and docosanoic acid (C22:0) were also found.

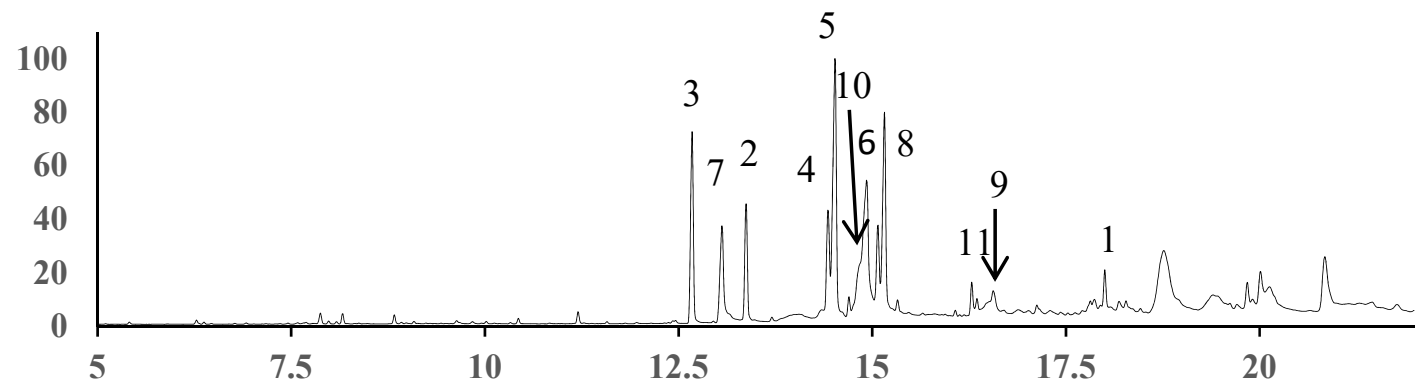

Figure 3. GC chromatograms of solution of samples. Peaks: 1, Tetradecanoic acid, methyl ester; 2, Hexadecanoic acid, methyl ester; 3, Hexadecanoic acid, 2-methyl-, methyl ester; 4, (9Z,12Z)-octadecadienoic acid, methyl ester; 5, (9Z,12Z,15Z)-octadecatrienoic acid, methyl ester; 6, Octadecanoic acid, methyl ester; 7, Heptadecanoic acid, methyl ester; 8, 18-Methylnonadecanoate, methyl ester; 9, cis-13-Eicosenoic acid, methyl ester; 10, Eicosanoic acid, methyl ester; 11, Docosanoic acid, methyl ester.

Table 4. FAs profile of the pollen oil by GC-MS analysis.

\begin{tabular}{|c|c|c|c|}
\hline No. & Components $^{a}$ & Content $(\%)^{b}$ & Molecular Formula \\
\hline 1 & Tetradecanoic acid, methyl ester & 2.95 & $\mathrm{C}_{15} \mathrm{H}_{30} \mathrm{O}_{2}$ \\
\hline 2 & Hexadecanoic acid, methyl ester & 7.67 & $\mathrm{C}_{17} \mathrm{H}_{34} \mathrm{O}_{2}$ \\
\hline 3 & Hexadecanoic acid, 2-methyl-, methyl ester & 25.66 & $\mathrm{C}_{18} \mathrm{H}_{36} \mathrm{O}_{2}$ \\
\hline 4 & (9Z,12Z)-Octadecadienoic acid, methyl ester & 3.8 & $\mathrm{C}_{19} \mathrm{H}_{34} \mathrm{O}_{2}$ \\
\hline 5 & $(9 Z, 12 Z, 15 Z)-O c t a d e c a t r i e n o i c ~ a c i d$, methyl ester & 36.25 & $\mathrm{C}_{19} \mathrm{H}_{32} \mathrm{O}_{2}$ \\
\hline 6 & Octadecanoic acid, methyl ester & 9.36 & $\mathrm{C}_{19} \mathrm{H}_{38} \mathrm{O}_{2}$ \\
\hline 7 & Heptadecanoic acid, methyl ester & 4.57 & $\mathrm{C}_{18} \mathrm{H}_{36} \mathrm{O}_{2}$ \\
\hline 8 & 18-Methylnonadecanoate, methyl ester & 3.73 & $\mathrm{C}_{21} \mathrm{H}_{42} \mathrm{O}_{2}$ \\
\hline 9 & cis-13-Eicosenoic acid, methyl ester & 1.39 & $\mathrm{C}_{21} \mathrm{H}_{40} \mathrm{O}_{2}$ \\
\hline 10 & Eicosanoic acid, methyl ester & 2.04 & $\mathrm{C}_{21} \mathrm{H}_{42} \mathrm{O}$ \\
\hline 11 & Docosanoic acid, methyl ester & 2.58 & $\mathrm{C}_{23} \mathrm{H}_{46} \mathrm{O}_{2}$ \\
\hline
\end{tabular}

${ }^{\mathrm{a}}$ expressed the FAs or corresponding methyl esters; ${ }^{\mathrm{b}}$ denoted the average normalized peak area percent. 


\subsection{Optimization of Extraction Method}

To determine the optimal extraction conditions and enhance the overall response of those investigated compounds in the HPLC analysis, extraction methods (refluxing and sonication), extraction solvents ( $100 \%, 90 \%, 75 \%, 50 \%$ and $25 \%$ methanol-water), number of extractions (1, 2, 3 and 4 times), and extraction times (30, 60, 90 and $120 \mathrm{~min}$ ) were investigated individually by using a univariate approach (default values: extraction method, sonication; extraction solvent, 50\% methanol; extraction number, 2 times; extraction time, $90 \mathrm{~min}$ ) on the sample BPSX. The results suggested that the established extracted method (each sample was extracted three times with 50\% methanol under ultrasonication condition for $90 \mathrm{~min}$ ) was optimal for HPLC analysis. The results are shown in Figure 4.

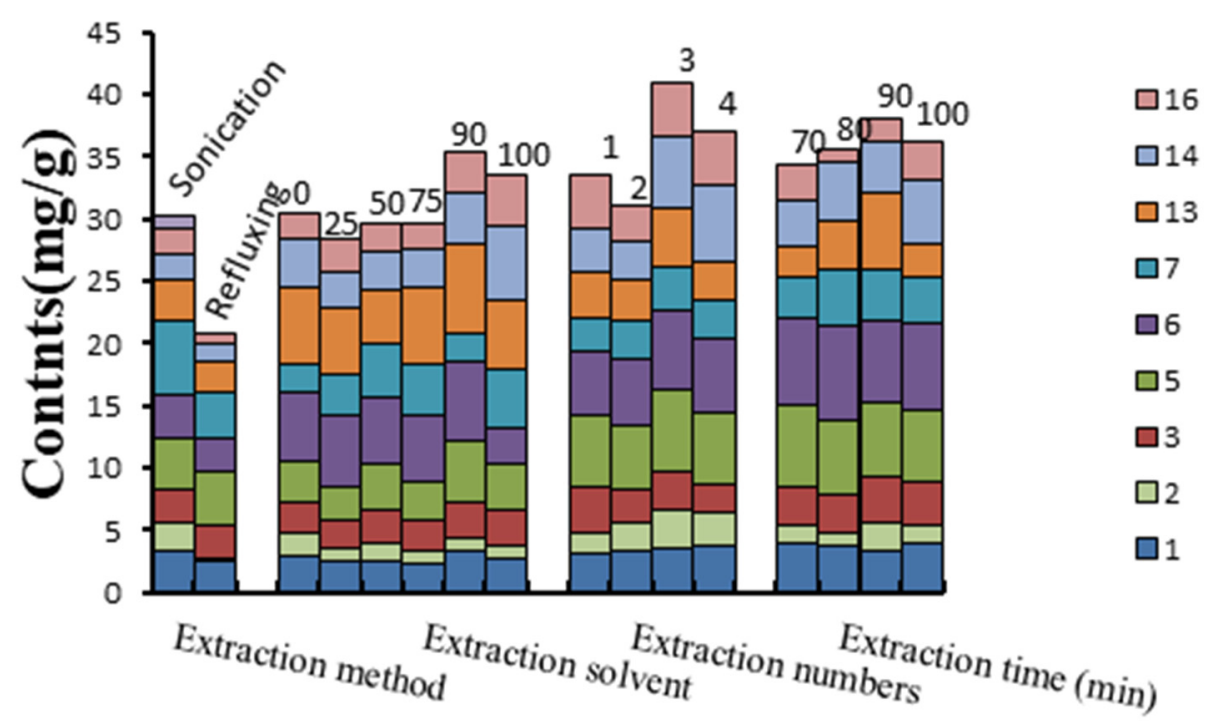

Figure 4. Effects of extraction method, solvent, number and time on the extraction efficiency of investigated standards in the sample (BPSX) of F. esculentum pollen. Note: luteolin (1), resveratrol (2), kaempferol (3), caffeic acid (5), chlorogenic acid (6), rutin (7), catechin (13), quercitrin (14), and tyrosol (16).

\subsection{HPLC Method Validation}

The HPLC method was validated by determining the linearity, limit of detection (LOD), limit of quantitation (LOQ), precision (inter-day and intra-day), repeatability, stability, and accuracy.

\subsubsection{Linearity, LODs and LOQs}

Linear calibration curves were established by plotting the peak area $(Y)$ versus the corresponding concentration $(X, \mu \mathrm{g} / \mathrm{mL})$ of each compound. All calibration curves exhibited good linear regressions $\left(R^{2} \geq 0.999\right)$ within the tested concentration ranges (Table 5). The lowest concentration of working solution for calibration use was diluted to a series of appropriate concentrations. They were then measured and checked until the signal-to-noise ratio $(\mathrm{S} / N)$ for each compound was approximately 3 for LOD and 10 for LOQ. The LODs and LOQs of all analytes were less than 0.23 and $0.64 \mu \mathrm{g} / \mathrm{mL}$, respectively. 
Table 5. Calibration curve data for nine reference compounds $(n=3)$.

\begin{tabular}{cccccc}
\hline Analytes * & Regression Equation & $\mathbf{R}^{\mathbf{2}}$ & $\begin{array}{c}\text { Linear Range } \\
(\mu \mathrm{g} / \mathrm{mL})\end{array}$ & LOD $(\mu \mathrm{g} / \mathrm{mL})$ & LOQ $(\mu \mathrm{g} / \mathrm{mL})$ \\
\hline 1 & $Y=83.34 X-446.99$ & $\mathrm{R}^{2}=0.99929$ & $4.00-600$ & 0.15 & 0.48 \\
2 & $Y=62.22 X-249.29$ & $\mathrm{R}^{2}=0.99973$ & $1.19-250$ & 0.07 & 0.37 \\
3 & $Y=19.68 X-105.92$ & $\mathrm{R}^{2}=0.99918$ & $1.50-250$ & 0.09 & 0.52 \\
5 & $Y=14.77 X-79.30$ & $\mathrm{R}^{2}=0.99919$ & $2.50-250$ & 0.11 & 0.63 \\
6 & $Y=54.15 X-295.55$ & $\mathrm{R}^{2}=0.99915$ & $1.00-200$ & 0.08 & 0.45 \\
7 & $Y=9.86 X-52.98$ & $\mathrm{R}^{2}=0.99914$ & $3.00-250$ & 0.14 & 0.39 \\
13 & $Y=63.91 X-351.28$ & $\mathrm{R}^{2}=0.99912$ & $1.50-500$ & 0.23 & 0.51 \\
14 & $Y=49.21 X-271.64$ & $\mathrm{R}^{2}=0.99916$ & $2.01-800$ & 0.15 & 0.46 \\
16 & $Y=64.13 X-352.54$ & $\mathrm{R}^{2}=0.99902$ & $1.08-500$ & 0.18 & 0.64 \\
\hline
\end{tabular}

* 1: luteolin, 2: resveratrol, 3: kaempferol, 5: caffeic acid, 6: chlorogenic acid, 7: rutin, 13: catechin, 14: quercitrin, 16: tyrosol.

\subsubsection{Precision, Repeatability, and Stability}

As all nine analytes could be detected and quantified in BPSX, BPSX was selected for the tests of precision, repeatability, and stability. The intra-day and inter-day precisions were successively evaluated by a prepared sample solution under optimal conditions within one day and duplicating this analysis once a day for three consecutive days, respectively. A stability test of the sample solution was conducted at $0,2,4,8,12,24$ and $48 \mathrm{~h}$. Repeatability was determined by analyzing six independently prepared solutions of sample BPSX. The relative standard deviation (RSD) of peak area for each marker compound was taken as a measure (Table 6). The RSD values of the reference compounds were found in the ranges of $0.71-1.45 \%, 0.95-2.25 \%, 0.47-2.06 \%$, and $1.60-3.15 \%$ for intra-day variations, inter-day variations, stability, and repeatability.

Table 6. Precision, repeatability, stability, and recovery of the analytes.

\begin{tabular}{|c|c|c|c|c|c|c|}
\hline \multirow{2}{*}{ Analytes } & \multicolumn{2}{|c|}{ Precision $(n=5)$} & \multirow{2}{*}{$\begin{array}{l}\text { Repeatability } \\
(n=6) \text { RSD (\%) }\end{array}$} & \multirow{2}{*}{$\begin{array}{c}\text { Stability }(n=6) \\
\text { RSD }(\%)\end{array}$} & \multicolumn{2}{|c|}{ Recovery $(n=3)$} \\
\hline & $\begin{array}{c}\text { Intra-Day } \\
\text { RSD (\%) }\end{array}$ & $\begin{array}{c}\text { Inter-Day } \\
\text { RSD (\%) }\end{array}$ & & & Mean (\%) & RSD (\%) \\
\hline 1 & 0.82 & 1.39 & 2.41 & 1.74 & 97.56 & 2.51 \\
\hline 2 & 1.23 & 1.24 & 2.05 & 0.94 & 98.69 & 1.99 \\
\hline 3 & 0.95 & 2.08 & 3.15 & 1.13 & 97.25 & 2.32 \\
\hline 5 & 1.17 & 2.25 & 2.53 & 2.04 & 99.64 & 3.49 \\
\hline 6 & 1.45 & 1.50 & 1.98 & 0.84 & 98.80 & 3.16 \\
\hline 7 & 1.11 & 1.61 & 2.47 & 0.98 & 100.56 & 2.98 \\
\hline 13 & 0.98 & 1.22 & 2.26 & 1.85 & 99.05 & 2.04 \\
\hline 14 & 0.71 & 0.95 & 1.60 & 0.47 & 101.12 & 1.63 \\
\hline 16 & 0.89 & 1.57 & 1.84 & 2.06 & 98.56 & 1.95 \\
\hline
\end{tabular}

1: luteolin, 2: resveratrol, 3: kaempferol, 5: caffeic acid, 6: chlorogenic acid, 7: rutin, 13: catechin, 14: quercitrin, 16: tyrosol.

\subsubsection{Recovery}

To check the accuracy of the analytical method, a recovery test was performed. In the test, a known amount of standards was added into $0.1 \mathrm{~g}$ of sample BPSX previously quantified. The spiked samples were extracted, processed and quantified per the methods above. Three replicates were performed for the test. The recovery values ranged from 97.25 to $102.07 \%$, and RSDs values were less than $3.49 \%$. These results indicate that the established method is accurate enough for quantitative analysis.

\subsection{Quantitative Determination of Nine Compounds}

The proposed analytical method was then successfully applied to the simultaneous quantification of seven BPSs collected from different areas in China. The results (Table 7) indicated that the 
contents of nine compounds varied greatly among different samples. The total content of these investigated compounds reached as high as $46.05 \mathrm{mg} / \mathrm{g}$ in sample BPNM, which was cultivated in Neimeng. However, the content was only $23.50 \mathrm{mg} / \mathrm{g}$ in BPGS, for the sample cultivated from Gansu. Flavonoids were considered the most abundant constituents in BPSs. Rutin, an important bioflavonoid, is abundantly found in various foodstuffs [17]. Rutin has been acknowledged for its protective and beneficial effects on various aspects of the biological system, rutin possesses sufficient potential for increasing immune activity by cellular and humoral mediated mechanisms [33]. Analyte 1 (luteolin) and analyte $\mathbf{2}$ (resveratrol) were detected in seven samples, the contents of analyte 1 varied from 6.23 to $10.94 \mathrm{mg} / \mathrm{g}$ and analyte 2 varied from 3.26 to $5.25 \mathrm{mg} / \mathrm{g}$. In addition, compound 6 could not be detected in many analyzed samples, only be detected in BPSX and BPNM, and the contents were 1.45 and $1.12 \mathrm{mg} / \mathrm{g}$, respectively.

Table 7. Contents of nine compounds in seven BPSs.

\begin{tabular}{ccccccccccc}
\hline \multicolumn{10}{c}{ Contents $^{\mathbf{a}}$ of $\mathbf{9}$ Compounds $(\mathbf{m g} / \mathbf{g})$} \\
\hline & $\mathbf{1}$ & $\mathbf{2}$ & $\mathbf{3}$ & $\mathbf{5}$ & $\mathbf{6}$ & $\mathbf{7}$ & $\mathbf{1 3}$ & $\mathbf{1 4}$ & $\mathbf{1 6}$ & Total \\
\hline BPSX & 9.46 & 5.25 & 3.67 & 3.47 & 1.45 & 1.45 & 2.40 & 2.66 & 2.28 & 32.09 \\
BPAH & 8.43 & 4.23 & 3.32 & 4.19 & ND $^{\mathrm{b}}$ & 1.34 & 9.38 & 4.91 & 1.66 & 37.46 \\
BPNM & 10.94 & 4.81 & 3.49 & 5.54 & 1.12 & 1.36 & 10.05 & 2.19 & 6.55 & 46.05 \\
BPHN & 8.68 & 5.03 & 2.59 & 6.00 & ND & ND & 2.47 & 5.19 & 3.27 & 33.23 \\
BPGS & 8.67 & 5.19 & ND & 5.57 & ND & ND & 4.07 & ND & ND & 23.50 \\
BPHB1 & 8.54 & 3.26 & ND & 5.02 & ND & 1.05 & 3.01 & ND & 3.28 & 24.16 \\
BPHB2 & 6.23 & 4.85 & 1.83 & 4.08 & ND & ND & 1.26 & 1.29 & 4.21 & 23.75 \\
\hline
\end{tabular}

1: luteolin, 2: resveratrol, 3: kaempferol, 5: caffeic acid, 6: chlorogenic acid, 7: rutin, 13: catechin, 14: quercitrin, 16: tyrosol. ${ }^{a}$ Content $=\frac{X \frac{V_{1} \text { (injection volume of standard solution) }}{\mathrm{V}_{2} \text { (injection volume of sample solution) }} \times \mathrm{V} \text { (sample volume) }}{\mathrm{M} \text { (sample amount) }}, \mathrm{X}$ : Contents of 9 compounds in sample solution. ${ }^{\mathrm{b}}$ Not detected.

Chlorogenic acid and caffeic acid are common bioactive compounds [34,35]. Chlorogenic acid has the effect of protecting liver, inhibits cancer cell growth and has a beneficial effect on ameliorating aging-related diseases [24]. Caffeic acid has also been reported have to a wide antibacterial effect [25]. From our data, analyte 6 (chlorogenic acid) varied from 1.12 to $1.45 \mathrm{mg} / \mathrm{g}$, and analyte 5 (caffeic acid) varied from 3.47 to $6.00 \mathrm{mg} / \mathrm{g}$. Look at all the data, the highest contents of analyte 1 is $10.94 \mathrm{mg} / \mathrm{g}$ in sample BPNM, the lowest contents of analyte 7 (rutin) is $1.05 \mathrm{mg} / \mathrm{g}$ in sample BPHB1.

\subsection{Activity Analysis}

\subsubsection{Analysis of $\alpha$-Glucosidase Inhibitory Activity}

Glucosidase is an important member of the sugar metabolism pathway in vivo, and $\alpha$-glucosidase is directly involved in the metabolic pathways of starch and glycogen [36]. By inhibiting $\alpha$-glucosidase, the chemical metabolism of sugar can be reduced, thereby achieving a hypoglycemic effect [37].

From Table 8, compound 3 (kaempferol), 7 (rutin), 8 (ergosterol peroxide), 10 (2- $\beta$-Dglucopyranosyloxy-1-hydroxytrideca-3,5,7,9,11-pentayne), 11 ( $\alpha$-D-Alt- $p$-OMe (N2-6) $\alpha$-D-Gle-p-OMe) and 12 (O- $\alpha$-D-glucopyranosyl-( $1 \rightarrow 4)-\alpha$-D-glucopyranosyl-( $1 \rightarrow 4)-\alpha$-D-glucopyranosyl-( $1 \rightarrow 2)-\beta$-Dfructofuranoside) had significant $\alpha$-glucosidase inhibitory activity compared with the positive control group, the $\mathrm{IC}_{50}$ value of the acarbose as the positive control group, which was $515.98 \mu \mathrm{g} / \mathrm{mL}$, and the $\mathrm{IC}_{50}$ value of the compound 3 was the lowest, which was $80.35 \mu \mathrm{g} / \mathrm{mL}$, and the $\mathrm{IC}_{50}$ value of the compound 7 was $188.42 \mu \mathrm{g} / \mathrm{mL}$, indicating that F. esculentum bee pollen has hypoglycemic effects. Notably, compounds 8, 10, 11 and $\mathbf{1 2}$ were tested for $\alpha$-glucosidase inhibitory activity for the first time, and the difference in their $\mathrm{IC}_{50}$ value was not significant. The inhibition mechanism of kaempferol on $\alpha$-glucosidase activity has been investigated by multispectroscopic methods and kaempferol had a 
significant inhibitory activity on $\alpha$-glucosidase with an $\mathrm{IC}_{50}$ value of $(1.16 \pm 0.04) \times 10^{-5} \mathrm{~mol} \mathrm{~L}^{-1}$ and $K_{\mathrm{i}}$ value of $(1.31 \pm 0.03) \times 10^{-5} \mathrm{~mol} \mathrm{~L}^{-1}[38]$.

Table 8. $\alpha$-glucosidase activity inhibition test results.

\begin{tabular}{cc}
\hline No. & IC $_{\mathbf{5 0}}(\boldsymbol{\mu g} / \mathbf{m L})$ \\
\hline Acarbose & 515.98 \\
3 & 80.35 \\
7 & 188.42 \\
8 & 452.50 \\
10 & 492.11 \\
11 & 318.44 \\
12 & 444.88 \\
\hline
\end{tabular}

\subsubsection{Analysis of Tyrosinase Inhibitory Activity}

From Table 9, compounds 1 (luteolin), 8 (ergosterol peroxide), $11 \quad(\alpha$-D-Alt-p-OMe (N2-6) $\alpha$-D-Glep-OMe), and 12 (O- $\alpha$-D-glucopyranosyl-(1 $\rightarrow 4)$ - $\alpha$-Dglucopyranosyl-(1 $\rightarrow 4)$ - $\alpha$-D-glucopyranosyl-( $1 \rightarrow 2)-\beta$-D-fructofuranoside) had significant tyrosinase inhibitory activity compared with the positive control group, the $\mathrm{IC}_{50}$ value of the kojic acid as the positive control group, which was $517.07 \mu \mathrm{g} / \mathrm{mL}$, indicating that F. esculentum bee pollen has hypoglycemic effect. The $\mathrm{IC}_{50}$ value of the compound 8 was the lowest, which was $202.37 \mu \mathrm{g} / \mathrm{mL}$, followed by the compound 8, which was $302.42 \mu \mathrm{g} / \mathrm{mL}$, compared with the positive control group, their $\mathrm{IC}_{50}$ value were low. The phenolic extracts from rape bee pollen have been shown to have anti-tyrosinase activity, which could reduce the content of melanin and inhibit the production of melanin in B16 mouse melanoma cells through the cAMP/MITF/TYR pathway [39], and the evaluation of the biological activity of isolated compounds from bee pollen of Quercus mongolica revealed that the polyamine derivatives with coumaroyl and caffeoyl moieties showed tyrosinase inhibition with $\mathrm{IC}_{50}$ values of $19.5-85.8 \mu \mathrm{M}[40]$.

Table 9. Tyrosinase inhibitory activity inhibition test results.

\begin{tabular}{cc}
\hline No. & IC $_{\mathbf{5 0}}(\boldsymbol{\mu g} / \mathrm{mL})$ \\
\hline Kojic acid & 517.07 \\
1 & 1643.11 \\
8 & 202.37 \\
11 & 302.42 \\
12 & 1750.08 \\
\hline
\end{tabular}

\subsubsection{Analysis of Acetylcholinesterase Inhibitory Activity}

From Table 10, compound 1 (luteolin), $\mathbf{3}$ (kaempferol), $\mathbf{7}$ (rutin), $\mathbf{8}$ (ergosterol peroxide), 10 (2- $\beta$-Dglucopyranosyloxy-1-hydroxytrideca-3,5,7,9,11-pentayne), 11 ( $\alpha$-D-Alt- $p$-OMe (N2-6) $\alpha$-D-Gle- $p$-OMe), and 12 (O- $\alpha$-D-glucopyranosyl-( $1 \rightarrow 4)$ - $\alpha$-D-glucopyranosyl-( $1 \rightarrow 4)$ - $\alpha$-D-glucopyranosyl-( $(1 \rightarrow 2)-\beta-$ $\mathrm{D}$-fructofuranoside) has strong acetylcholinesterase inhibitory activity, the difference between the positive group was not significant. $\mathrm{IC}_{50}$ value of the huperzine $\mathrm{A}$ as the positive control group, which was $502.98 \mu \mathrm{g} / \mathrm{mL}$, compound $\mathbf{1 0}$ was the highest, with $\mathrm{IC}_{50}$ values of $521.14 \mu \mathrm{g} / \mathrm{mL}$, compound 1 was the lowest, with $\mathrm{IC}_{50}$ values of $476.25 \mu \mathrm{g} / \mathrm{mL}$. At present, there are few studies on the inhibitory activity of acetylcholinesterase in bee pollen. Acetylcholinesterase is involved in the development and maturation of cells and can promote the development of neurons and nerve regeneration [41]. 
Table 10. Acetylcholinesterase inhibitory activity inhibition test results.

\begin{tabular}{cc}
\hline No. & IC $_{\mathbf{5 0}}(\boldsymbol{\mu g} / \mathbf{m L})$ \\
\hline Huperzine A & 502.98 \\
1 & 476.25 \\
3 & 504.34 \\
7 & 491.93 \\
8 & 500.14 \\
10 & 521.14 \\
11 & 516.21 \\
12 & 507.44 \\
\hline
\end{tabular}

\section{Conclusions}

In this study, 16 compounds were isolated from F. esculentum bee pollen, including flavone compounds, phenolic acids, terpenoids, and 11 fatty acids were analyzed in F. esculentum bee pollen oil. Saturated fatty acids were $30.86 \%$, unsaturated fatty acids were $69.14 \%$, of which $(9 Z, 2 Z, 15 Z)$-octadecatrienoic acid content was as high as $36.25 \%$, indicating that the unsaturated fatty acid content of $F$. esculentum bee pollen is high, and it is a green and healthy food. A HPLC method with high stability, good repeatability and high precision was established, and the content of nine compounds in F. esculentum bee pollen from seven different habitats was quantitatively analyzed. From the results, the content of bee pollen collected in Neimeng was the highest $(46.05 \mathrm{mg} / \mathrm{g})$, and the content of bee pollen collected in Gansu was the lowest (23.50 mg/g). Kaempferol (3) showed high $\alpha$-glucosidase inhibitory activity $\left(\mathrm{IC}_{50}: 80.35 \mu \mathrm{g} / \mathrm{mL}\right.$ ), ergosterol peroxide (8) showed high tyrosinase inhibitory activity $\left(\mathrm{IC}_{50}: 202.37 \mu \mathrm{g} / \mathrm{mL}\right.$ ), and luteolin (1) had strongly acetylcholinesterase inhibitory activity ( $\mathrm{IC}_{50}: 476.25 \mu \mathrm{g} / \mathrm{mL}$ ). Furthermore, bee pollen has been used as a health food supplement for many years due to its abundant nutrient properties including proteins, polysaccharide, and lipids [42]. The average protein content of bee pollen is $24.65 \%$ (10-40\% dry weight) [9]. The proportion of amino acids in bee pollen is also high and there are many kinds of amino acids. Studies have proved that the protein in bee pollen accounts for $29.18 \%$ of its dry weight [43]. Polysaccharides, namely carbohydrates, are the most abundant component in bee pollen, accounting for $18.9-57.6 \%$ of bee pollen [44]. Lipids are an important component of bee pollen, and their content accounts for about $1-20 \%$ of its dry weight [45]. Other trace elements including vitamins, minerals, enzymes, nucleic acids have also been found in pollen. Therefore, it has antioxidant, anti-inflammatory and immune-enhancing capabilities [46-49]. Our research has proved that isolated metabolites possess potential anti-aging activity. These compounds could work synergistically with nutrients in pollen and provide more evidence for the beneficial effects of pollen. In conclusion, F. esculentum bee pollen is a kind of natural nutrition and health food for anti-aging, beauty and improving human immunity.

At present, most of reports on bee pollen are aimed at the study of extracts. Therefore, the innovation of this paper is the separation and identification of extracts. The quantitative analyses of bee pollen from seven different places of origin were also carried out.

Supplementary Materials: The following are available online.

Author Contributions: Conceptualization: N.B., C.-T.H. and W.C.; Data curation: F.L. and S.G.; Formal analysis: F.L. and S.P.; Methodology: F.L. and S.Z.; Submitting the manuscript: S.Z.; Writing and revising the manuscript:S.G.

Funding: This research was funded by National Natural Science Foundation of China (Grant No.31570348).

Conflicts of Interest: The authors declare no competing interest. 


\section{References}

1. Almeida-Muradian, L.B.; Pamplona, L.C.; Coimbra, S.; Monika, B.O. Chemical composition and botanical evaluation of dried bee pollen pellets. J. Food Comp. Anal. 2005, 18, 105-111. [CrossRef]

2. Campos, M.G.R.; Frigerio, C.; Lopes, J. What is the future of bee-pollen? J. ApiProd. ApiMed. Sci. 2010, 2, 131-144. [CrossRef]

3. Arruda, V.A.S.D.; Pereira, A.A.S.; Freitas, A.S.D.; Ortrud, M.B.; Almeida-Muradian, L.B.D. Dried bee pollen: B complex vitamins, physicochemical and botanical composition. J. Food Comp. Anal. 2013, 29, 100-105. [CrossRef]

4. Melo, I.L.P.D.; Almeidamuradian, L.B.D. Stability of antioxidants vitamins in bee pollen samples. Química Nova 2010, 33, 514-518. [CrossRef]

5. Campos, M.G.; Markham, K.R.; Mitchell, K.A.; Cunha, A.P.D. An approach to the characterization of bee pollens via their flavonoid/phenolic profiles. Phytochem. Anal. 2015, 8, 181-185. [CrossRef]

6. Zhou, J.; Qi, Y.; Ritho, J.; Zhang, Y.; Zheng, X.; Wu, L.; Li, Y.; Sun, L. Flavonoid glycosides as floral origin markers to discriminate of unifloral bee pollen by LC-MS/MS. Food Control 2015, 57, 54-61. [CrossRef]

7. Xu, X.; Gao, Y.; Sun, L. Free and esterified triterpene alcohol composition of bee pollen from different botanical origins. Food Res. Int. 2012, 48, 650-656. [CrossRef]

8. Nogueira, C.; Iglesias, A.; Feás, X.; Estevinho, L.M. Commercial bee pollen with different geographical origins: A comprehensive approach. Int. J. Mol. Sci. 2012, 13, 11173-11187. [CrossRef]

9. Pascoal, A.; Rodrigues, S.; Teixeira, A.; Feás, X.; Estevinho, L.M. Biological activities of commercial bee pollens: Antimicrobial, antimutagenic, antioxidant and anti-inflammatory. Food Chem. Toxicol. 2014, 63, 233-239. [CrossRef]

10. Li, F.; Yuan, Q.; Farzana, R. Isolation, purification and immunobiological activity of a new water-soluble bee pollen polysaccharide from Crataegus pinnatifida Bge. Carbohydr. Polym. 2009, 78, 80-88. [CrossRef]

11. Leja, M.; Mareczek, A.; Wyżgolik, G.; Klepacz-Baniak, J.; Czkońska, K. Antioxidative properties of bee pollen in selected plant species. Food Chem. 2007, 100, 237-240. [CrossRef]

12. Medeiros, K.C.; Figueiredo, C.A.; Figueredo, T.B.; Freire, K.R.; Santos, F.A.; Alcantara-Neves, N.M.; Silva, T.M.; Piuvezam, M.R. Anti-allergic effect of bee pollen phenolic extract and myricetin in ovalbumin-sensitized mice. J. Ethnopharmacol. 2008, 119, 41-46. [CrossRef] [PubMed]

13. Linskens, H.F.; Jorde, W. Pollen as food and medicine: A review. Econ. Botany 1997, 51, 78-86. [CrossRef]

14. Park, H.K.; Kim, S.K.; Lee, S.W.; Chung, J.H.; Lee, B.C.; Na, S.W.; Park, C.G.; Kim, Y.O. A herbal formula, comprising Panax ginseng and bee-pollen, inhibits development of testosterone-induced benign prostatic hyperplasia in male Wistar rats. Saudi J. Biol. Sci. 2017, 24, 1555-1561. [CrossRef] [PubMed]

15. Yang, X.P.; Guo, D.Y.; Zhang, J.M.; Wu, M.C. Characterization and antitumor activity of pollen polysaccharide. Int. Immunopharmacol. 2007, 7, 401-408. [CrossRef] [PubMed]

16. Morais, M.; Moreira, L.; Feás, X.; Estavinho, L.M. Honeybee-collected pollen from five Portuguese Natural Parks: Palynological origin, phenolic content, antioxidant properties and antimicrobial activity. Food Chem. Toxicol. 2011, 49, 1096-1101. [CrossRef] [PubMed]

17. Murakami, M.; Tsukada, O.; Okihara, K.; Hashimoto, K. Beneficial effect of honeybee-collected pollen lump extract on benign prostatic hyperplasia (BPH) - A double-blind, placebo-controlled clinical trial. Food Sci. Technol. Res. 2008, 14, 306-310. [CrossRef]

18. Naureen, S.; Chaudhry, F.; Munawar, M.A.; Ashral, M.; Hamid, S.; Khan, M.A. Biological evaluation of new imidazole derivatives tethered with indole moiety as potent $\alpha$-glucosidase inhibitors. Bioorganic Chem. 2018, 76, 365-369. [CrossRef]

19. Liu, X.G.; Huang, M.Y.; Gao, P.Y.; Liu, C.F.; Sun, Y.Q.; Lv, M.C.; Yao, G.D.; Zhang, L.X.; Li, D.Q. Bioactive constituents from, Medicago sativa, L. with antioxidant, neuroprotective and acetylcholinesterase inhibitory activities. J. Funct. Foods 2018, 45, 371-380. [CrossRef]

20. Wu, H.K.; Sun, T.; Zhao, F.; Zhang, L.P.; Li, G.; Zhang, J. New diterpenoids isolated from, Leonurus japonicus, and their acetylcholinesterase inhibitory activity. Chin. J. Nat. Med. 2017, 15, 860-864. [CrossRef]

21. Thi, N.H.; Thi, D.H.; Viet, H.D.; Thanh, P.K.; Raal, A.; Morita, H. Huperphlegmines A and B, two novel, Lycopodium, alkaloids with an unprecedented skeleton from Huperzia phlegmaria, and their acetylcholinesterase inhibitory activities. Fitoterapia 2018, 129, 267-271. 
22. Hassan, M.; Ashraf, Z.; Abbas, Q.; Raza, H.; Seo, S.Y. Exploration of novel human tyrosinase inhibitors by molecular modeling, docking and simulation studies. Interdiscip. Sci. 2016, 10, 68-80. [CrossRef] [PubMed]

23. Takashi, M.; Takuya, N.; Takehiro, I.; Ken-ichi, N. Chemical synthesis and tyrosinase-inhibitory activity of isotachioside and its related glycosides. Carbohydr. Res. 2018, 465, 22-28.

24. Fan, M.; Zhang, G.; Hu, X.; Xu, X.; Gong, D. Quercetin as a tyrosinase inhibitor: Inhibitory activity, conformational change and mechanism. Food Res. Int. 2017, 100, 226-333. [CrossRef] [PubMed]

25. Lou, L.L.; Liu, S.; Yan, Z.Y.; Lin, B.; Wang, X.B.; Huang, X.X.; Song, S.J. Tetrahydro- $\beta$-Carboline alkaloids from, Carthamus tinctorius L. with tyrosinase inhibitory activity. Phytochem. Lett. 2017, 22, 107-112. [CrossRef]

26. Shimizu, K.; Kondo, R.; Sakai, K. Inhibition of tyrosinase by flavonoids, stilbenes and related 4-substituted resorcinols: Structure-activity investigations. Planta Med. 2000, 66, 11-15. [CrossRef] [PubMed]

27. Silva, A.P.D.; Silva, N.D.F.; Andrade, E.H.A.; Gratieri, T.; Setzer, W.N.; Maia, J.G.S.; Silva, J.K.R.D. Tyrosinase inhibitory activity, molecular docking studies and antioxidant potential of chemotypes of Lippia origanoides (Verbenaceae) essential oils. PLoS ONE 2017, 12, e0175598. [CrossRef]

28. Hakme, E.; Lozano, A.; Gómezramos, M.M.; Hernando, M.D.; Fernánde-Alba, A.R. Non-target evaluation of contaminants in honey bees and pollen samples by gas chromatography time-of-flight mass spectrometry. Chemosphere 2017, 184, 1310-1319. [CrossRef]

29. Ols, M.L.; Cullen, J.L.; Turqueti-Neves, A.; Giles, J.; Shlomchik, M.J. Dendritic cells regulate extrafollicular autoreactive b cells via t cells expressing Fas and Fas ligand. Immunity 2016, 45, 1052-1065. [CrossRef]

30. Alleva, J.M.; Tylka, T.L.; Am, K.V.D. The functionality appreciation scale (FAS): Development and psychometric evaluation in U.S. community women and men. Body Image 2017, 23, 28-44. [CrossRef]

31. Liao, C.C.; Chen, S.C.; Huang, H.P.; Wang, C.J. Gallic acid inhibits bladder cancer cell proliferation and migration via regulating fatty acid synthase (FAS). J. Food Drug Anal. 2017, 26, 620-627. [CrossRef] [PubMed]

32. Noyori, O.; Nakayama, E.; Maruyama, J.; Yoshida, R.; Takada, A. Suppression of Fas-mediated apoptosis via steric shielding by filovirus glycoproteins. Biochem. Biophys. Res. Commun. 2013, 441, 994-998. [CrossRef] [PubMed]

33. Ganeshpurkar, A.; Saluja, A.K. Protective effect of rutin on humoral and cell mediated immunity in rat model. Chem. Biol. Interact. 2017, 273, 154-159. [CrossRef] [PubMed]

34. Li, Q.Y.; Zhu, Y.F.; Zhang, M.; Li, C.; Zhang, Z.; Du, Y.L.; Ren, G.Q.; Tang, J.M.; Zhou, M.K.; Shi, X.J. Chlorogenic acid inhibits hypoxia-induced pulmonary artery smooth muscle cells proliferation via, c-Src and Shc/Grb2/ERK2 signaling pathway. Eur. J. Pharmacol. 2015, 751, 81-88. [CrossRef] [PubMed]

35. Xie, J.; Yang, F.; Zhang, M.; Lam, C.; Qiao, Y.; Jia, X.; D D Zhang, D.; Ge, Y.; Fu, L.; Xie, D. Antiproliferative activity and SARs of caffeic acid esters with mono-substituted phenylethanols moiety. Bioorg. Med. Chem. Lett. 2017, 27, 131-134. [CrossRef] [PubMed]

36. González-Montoya, M.; Hernández-Ledesma, B.; Mora-Escobedo, R.; Martínez-Villaluenga, C. Bioactive peptides from germinated soybean with anti-diabetic potential by inhibition of dipeptidyl peptidase-IV, $\alpha$-amylase, and $\alpha$-glucosidase enzymes. Int. J. Mol. Sci. 2018, 19, 2883. [CrossRef] [PubMed]

37. Xie, Z.; Wang, G.; Wang, J.; Chen, M.; Peng, Y.; Li, L.; Deng, B.; Chen, S.; Li, W. Synthesis, biological evaluation, and molecular docking studies of novel isatin-thiazole derivactives as $\alpha$-glucosidase inhibitors. Molecules 2017, 22, 659 .

38. Peng, X.; Zhang, G.; Liao, Y.; Gong, D. Inhibitory kinetics and mechanism of kaempferol on $\alpha$-glucosidase. Food Chem. 2016, 190, 207-215. [CrossRef]

39. Sun, L.P.; Yan, G.; Zhang, Y.X.; Zhuang, Y.L. Antioxidant and anti-tyrosinase activities of phenolic extracts from rape bee pollen and inhibitory melanogenesis by cAMP/MITF/TYR pathway in B16 mouse melanoma cells. Front. Pharmacol. 2017, 8, 104. [CrossRef]

40. Kim, S.B.; Liu, Q.; Ahn, J.H.; Jo, Y.H.; Turk, A.; Hong, I.P.; Han, S.M.; Hwang, B.Y.; Lee, M.K. Polyamine derivatives from the bee pollen of Quercus mongolica with tyrosinase inhibitory activity. Bioorg. Chem. 2018, 81, 127-133. [CrossRef]

41. Liu, X.; Bian, J.; Li, D.; Liu, C.; Xu, S.; Zhang, G.; Zhang, L.; Gao, P. Structural features, antioxidant and acetylcholinesterase inhibitory activities of polysaccharides from stem of Physalis alkekengi L. Ind. Crops Prod. 2019, 129, 654-661. [CrossRef]

42. Cheng, N.; Ren, N.; Gao, H.; Lei, X.; Zheng, J.; Cao, W. Antioxidant and hepatoprotective effects of schisandra chinensis pollen extract on CCl4-induced acute liver damage in mice. Food Chem. Toxicol. 2013, 55, 234-240. [CrossRef] [PubMed] 
43. Rebelo, K.S.; Ferreira, A.G.; Carvalho-Zilse, G.A. Physicochemical characteristics of pollen collected by Amazonian stingless bees. Cienc. Rural 2016, 46, 927-932. [CrossRef]

44. Vanderplanck, M.; Leroy, B.; Wathelet, B.; Wattiez, R.; Michez, D. Standardized protocol to evaluate pollen polypeptides as bee food source. Apidologie 2014, 45, 192-204. [CrossRef]

45. Ares, A.M.; Valverde, S.; Bernal, J.L.; Nozal, M.J.; Bernal, J. Extraction and determination of bioactive compounds from bee pollen. J. Pharma Biomed. Anal. 2018, 147, 110-124. [CrossRef]

46. Denisow, B.; Denisow-Pietrzyk, M. Biological and therapeutic properties of bee pollen: A review. J. Sci. Food Agric. 2016, 96, 4303-4309. [CrossRef] [PubMed]

47. Puerto, N.; Prieto, G.; Castro, R. Chemical composition and antioxidant activity of pollen. Chil. J. Agric. Anim. Sci. 2015, 31, 115-126.

48. Sattler, J.A.G.; de Melo, A.A.M.; do Nascimento, K.S.; de Melo, I.L.P.; Mancini-Filho, J.; Sattler, A.; de Almeida-Muradian, L.B. Essential minerals and inorganic contaminants (barium, cadmium, lithium, lead and vanadium) in dried bee pollen produced in Rio Grande do Sul State, Brazil. Food Sci. Technol. 2016, 36, 505-509. [CrossRef]

49. Chen, S.N.; Zhao, H.A.; Cheng, N.; Cao, W. Rape bee pollen alleviates dextran sulfate sodium (DSS)-induced colitis by neutralizing IL-1 $\beta$ and regulating the gut microbiota in mice. Food Res. Int. 2019, 122, 241-251. [CrossRef]

Sample Availability: Samples of the compounds are not available from the authors.

(C) 2019 by the authors. Licensee MDPI, Basel, Switzerland. This article is an open access article distributed under the terms and conditions of the Creative Commons Attribution (CC BY) license (http://creativecommons.org/licenses/by/4.0/). 